\title{
Polymorphism in the 5'-noncoding region of the bovine growth hormone receptor gene and its association with meat production traits in cattle
}

\author{
Andrzej MAJ, Jolanta OPRZĄDEK, Artur OPRZĄDEK, Edward DYMNICKI, \\ Lech ZWIERZCHOWSKI*
}

Institute of Genetics and Animal Breeding, Polish Academy of Sciences, Jastrzębiec, 05-552 Wólka Kosowska, Poland

(Received 2 June 2003; accepted 12 October 2004)

\begin{abstract}
The single and combined effects of polymorphism in the 5'-noncoding region of the bovine growth hormone receptor (GHR) gene was examined on the traits related to feed intake and meat production in beef cattle. Four different single nucleotide polymorphisms (SNP) were analysed. Seventy-one young bulls belonging to four beef breeds (Charolais, Limousin, Aberdeen Angus, Hereford) and one dual purpose breed (Simmental) were included in the study. The traits analysed were daily weight gain, feed intake and conversion, and carcass parameters. The results showed that genetic variants at the 5'-noncoding region of the bovine GHR gene had a marked effect on beef production traits. The (-) allele at the polymorphic AluI site appeared favourable for weight of carcass and percentage of valuable cuts. The animals with the $+/+$ genotype for the RFLP-AccI polymorphism seemed better for the percent of lean in valuable cuts, while those with the $+/+$ genotype at the polymorphic Fnu4HI site appeared superior for daily gain and feed conversion during the feed test period. A higher percent of lean in valuable cuts was shown for the bulls of the -/- genotypes at the $N$ siI site. In addition, statistically significant associations were shown between combined GHR genotypes and feed consumption, carcass weight and dimensions.
\end{abstract}

growth hormone receptor / gene polymorphism / cattle / meat production traits

Résumé - Polymorphisme dans la région 5' non codante du gène du récepteur de l'hormone de croissance associé aux caractères de production de viande chez les bovins. L'effet du polymorphisme dans la région 5' non codante du gène du récepteur de l'hormone de croissance bovine (GHR) sur les caractères associés à la consommation de fourrage et à la production de viande chez les bovins de boucherie a été examiné. Quatre polymorphismes nucléotidiques simples (SNP ; single nucleotide polymorphisms) différents ont été analysés. Soixante et onze jeunes taureaux appartenant à 4 races bovines à viande (Charolaise, Limousine, Aberdeen Angus, Hereford) et une race bovine mixte (Simmental) ont été inclus dans l'étude. Les caractéristiques suivantes ont été analysées: gain moyen quotidien, consommation de fourrage, indice de consommation et qualité de la carcasse. Les résultats montrent que les variants génétiques pour la région 5' non codante du gène

* Corresponding author: 1.zwierzchowski@ighz.pl 
du GRH ont un effet significatif sur la production de viande de boeuf. L'allèle $(-)$ dans le site polymorphe $A l u \mathrm{I}$ semble favorable au poids de la carcasse et à la teneur en morceaux nobles. Les animaux possédant le génotype +/+ pour le polymorphisme RFLP-AccI tendent à améliorer leur teneur en muscle dans les morceaux nobles, tandis que les animaux possédant le génotype $+/+$ dans le site polymorphique Fnu4HI ont amélioré la vitesse de croissance et l'indice de consommation. Pour la teneur en muscle dans les morceaux nobles, la meilleure performance a été observée chez les taureaux possédant le génotype -/- dans le site NsiI. De plus, les génotypes combinés du gène du GHR ont eu des effets significatifs sur la consommation de fourrage, le poids et les dimensions de la carcasse.

récepteur hormone de croissance / polymorphisme génétique / bovins / caractères de production de viande

\section{INTRODUCTION}

The biological effects of growth hormone $(\mathrm{GH})$ involve a variety of tissues and the metabolism of all nutrient classes: carbohydrates, lipids, proteins, and minerals. These coordinated changes in tissue metabolism alter nutrient partitioning and thus play a key role in increasing growth performance or milk yield [5]. Therefore, there is a great interest in using growth hormone to improve production traits in cattle. Moreover, the gene coding for GH was considered a promising candidate as a marker for selection purposes [25].

Growth hormone actions on target cells depend on the GH receptor (GHR) [3]. The GH binding to GHR causes its dimerisation, activation of the GHR-associated JAK2 tyrosine kinase, and tyrosyl phosphorylation of both JAK2 and GHR [28]. These events activate a variety of signalling molecules, including MAP kinases, protein kinase C, and STAT transcription factors.

The GH receptor is a member of the cytokine/hematopoietin superfamily of receptors. It contains a single transmembrane domain comprising 24-amino acids (a.a.), extracellular hormone binding domain, and a long cytoplasmic domain [17]. In cattle, the GHR gene is encoded by a single gene located on chromosome 20 [22]. The gene coding for bovine GHR consists of 9 exons (from 2 to 10) in the translated part and of a long 5 '-noncoding region, that includes 9 untranslated exons $-1 \mathrm{~A}, 1 \mathrm{~B}, 1 \mathrm{C}, 1 \mathrm{D}, 1 \mathrm{E}$, $1 \mathrm{~F}, 1 \mathrm{G}, 1 \mathrm{H}, 1 \mathrm{I}[14]$. Exons from the untrans- lated region are spliced alternatively and each of them has its own transcription start site. A LINE-1 element from the family of retrotransposons, about $1.2 \mathrm{Kbp}-\mathrm{long}$, was found upstream from exon 1A [18].

Heterogeneity in the 5' untranslated region (UTR) of the growth hormone receptor gene has been shown in different species of mammals. Nine variants of GHR mRNA have been identified in humans (V1-V9; [10]) and cattle (1A-1I; [14]). In cattle, variant $1 \mathrm{~A}$ is exclusively expressed in the liver and transcriptionally controlled by the liverenriched factor, hepatocyte nuclear factor-4 (HNF-4; [15]). Moreover, it has been suggested that expression of different transcripts are under developmental- and tissuedependent regulation [10, 20].

Several polymorphic sequences have been identified in the bovine GHR gene. Falaki et al. [6] reported nine RFLP-TaqI genotypes within the GHR gene sequences coding for the intracellular C-terminal part of the receptor. Moisio et al. [21] detected three bovine GHR gene variants differing in the length of a 3' flanking region $(311,320$, and 325-bp fragments) and one differing in a C/G transversion at position +2313 . Three single nucleotide substitutions (SNPs) in the 5'-flanking region of the bovine GHR gene, recognised as RFLP with restriction endonucleases $A l u \mathrm{I}, A c c \mathrm{I}$, and $S t u \mathrm{I}$, were identified by Aggrey et al. [1]. Hale et al. [12] reported in Angus cattle the presence of the polymorphic TG-repeat (microsatellite), located $90 \mathrm{bp}$ upstream from the major transcription start site in the GHR gene. The 
polymorphic variants of the bovine GHR gene were reported in the promoter P1 upstream of a starting site of exon 1A [8], next identified as an $\mathrm{A} / \mathrm{G}$ transition at pos. -154 , recognised as RFLP with NsiI endonuclease [9].

We found a new RFLP in the bovine GHR gene at the Fnu4HI/TseI site [19]; a $\mathrm{C} / \mathrm{T}$ transition was determined by sequencing at position -1104 . Two alleles and three genotypes were identified within the analysed populations of dairy and beef cattle. We showed that the newly found RFLP-Fnu4HI/ TseI polymorphic site and RFLP-AluI and - AccI previously identified by Aggrey et al. [1] are located within the $1.2 \mathrm{~kb}$ LINE-1 retrotransposon upstream from the P1 promoter for exon 1A. Sequencing of the 5'noncoding region of the GHR gene (Maj A. andZwierzchowski L.; GenBank AY249137; unpublished data) enabled the identification of additional nucleotide substitutions. All of them were located within the $\mathrm{P} 1$ promoter: $\mathrm{G} / \mathrm{C}$ at position $-475, \mathrm{C} / \mathrm{T}(-262)$, and $\mathrm{C} / \mathrm{T}$ (-344). The two C/T transitions were previously reported by Hale et al. [12] as a characteristic of the $B$. indicus species.

It was shown that some performance traits of cattle, e.g. milk yield and composition, are correlated with the polymorphism of GHR $[1,6]$. Moreover, we found significant differences in the ligand binding parameters to liver GHR (dissociation constant $-\mathrm{K}_{\mathrm{d}}$ ) between RFLP-AluI and -AccI genotypes within the 5'-flanking region of the bovine GHR gene in Polish Friesians [11].

The objective of this study was to examine the effect of polymorphism in the 5 '-noncoding region of the bovine GHR gene on the traits related to meat production in cattle. Four different single nucleotide polymorphisms (SNPs) were analysed, including one recently identified by the authors the RFLP-Fnu4HI. For that, the effects of the combined GHR genotypes were estimated. The traits analysed were daily weight gain, feed intake and conversion, and carcass parameters.

\section{MATERIALS AND METHODS}

\subsection{Animals}

The study was performed on 71 bulls belonging to 5 cattle breeds - Charolais (18), Limousin (16), Aberdeen Angus (10), Hereford (16) - born in beef herds and Simmental (11) - born in dairy herds. The bulls of each group were the randomly chosen progeny of 5-7 sires. At the age of 6-7 months, they were transferred to the Institute farm, Jastrze biec. After reaching the age of 9 months the animals were fed ad libitum a total mixed ration (TMR), consisting of $75 \%$ corn silage, $20 \%$ concentrates, and 5\% hay. The test period for feed intake and conversion lasted 60 days (from the beginning of the 13th to slaughter). During that time the individual intake was recorded daily and chemical composition of the TMR was analysed weekly. Mean composition of $1 \mathrm{~kg}$ TMR was $451 \mathrm{~g}$ DM, 0.36 UFV, and $40.95 \mathrm{~g}$ PDI (INRA system) [13]. The bulls were weighed monthly, then weighed and measured at the age of 15 months and slaughtered in the local abattoir. Valuable cuts from the right carcassside were obtained and dissected, separating lean, bones and fat. All performance traits analysed in this study [30] and the breed effects on carcass traits [24] have been reported previously.

Approximately $10 \mathrm{~mL}$ blood was withdrawn by an authorised veterinarian from each animal and placed into test tubes containing $\mathrm{K}_{2}$ EDTA. All experimental procedures involving animals were approved by the Local Ethics Commission (permission No. 67/2001).

\subsection{Determination of GHR polymorphism}

DNA was isolated from the blood by the method of Kanai et al. [16]. For the genotyping of the animals for GHR RFLP-AluI and $-A c c \mathrm{I}$, the method described by Aggrey et al. [1] was previously adapted and modified so that one long 1934-bp DNA fragment was amplified instead of two shorter 
fragments [11]. The amplified DNA extended from position -1866 to +68 in the GHR gene. The sequence of the primers were as follows:

forward - 5' - TGCGTGCACAGCAGCTCAACC-3';

reverse - 5' - GGCAAACAGTGCGGGGTTGGA-3'

PCR was performed in a volume of $12 \mu \mathrm{L}$ using $1.4 \mu \mathrm{L}$ (approx. $100 \mathrm{ng}$ ) template DNA, $0.25 \mu \mathrm{M}$ primers, PCR buffer (50 mM KCl; $10 \mathrm{mM}$ Tris- $\mathrm{HCl}, \mathrm{pH} 8.0$; $1.5 \mathrm{mM} \mathrm{MgCl}_{2}$ ), $2.5 \mathrm{mMdNTPs}$, and 1 unit of Taq polymerase (InGen, Sieradz, Poland). Amplification was carried out for 35 cycles: $95^{\circ} \mathrm{C}$ for $60 \mathrm{~s}, 66^{\circ} \mathrm{C}$ for $80 \mathrm{~s}$, and $72^{\circ} \mathrm{C}$ for $120 \mathrm{~s}$. The $10-\mu \mathrm{L}$ aliquots of the PCR product were separately digested at $37^{\circ} \mathrm{C}$ with 5 units of the restriction enzymes: $A l u \mathrm{I}$ and AccI (BioLabs, New England, USA) for $3 \mathrm{~h}$. The digested DNA fragments were then separated by electrophoresis in $2 \%$ agarose (Gibco, BRL, England) in $1 \times$ TBE buffer (0.09 M Tris-boric acid, 0.002 M EDTA) with $0.5 \mathrm{mg} \cdot \mathrm{mL}^{-1}$ ethidium bromide (Et$\mathrm{Br}$ ) added to the gels, visualised under UV light, and scanned in an FX Molecular Imager apparatus (Bio-Rad, Hercules, $\mathrm{Ca}$, USA).

To genotype the GHR gene at the Fnu4HI site, the following primers were used to amplify the 836-bp fragment, from -1866 to -1031 nucleotide (nt):

forward - 5'-TGCGTGCACAGCAGCTCAACC-3'

reverse - 5'-AGCAACCCCACTGCTGGGCAT-3'

The amplified DNA was digested for 3 hours at $37{ }^{\circ} \mathrm{C}$ with five units of $F n u 4 \mathrm{HI}$ restriction endonuclease (BioLabs, New England, USA). Restriction products were separated by electrophoresis in 2\% agarose (Gibco, BRL, England) in $1 \times$ TBE buffer with Et-Br added to the gels, visualised under UV light and scanned.

The primers for the analysis of RFLP polymorphism at the $N$ siI site were designed based on the bovine GHR gene sequences (GenBank; AF126288 and U15731). forward - 5'-CTGGCGTATGGTCTTTGTCA-3,

reverse - 5'-TGGTCTTGCTGCTTTCCTAT-3'

Amplification was carried out for 35 cycles: $95^{\circ} \mathrm{C}$ for $20 \mathrm{~s}, 66^{\circ} \mathrm{C}$ for $30 \mathrm{~s}$, and $72^{\circ} \mathrm{C}$ for 40 s. A 318-bp DNA fragment was amplified, from position -319 to $-2 \mathrm{nt}$ in the GHR gene promoter P1, and digested with Nsi I endonuclease. The restriction products were analysed electrophoretically.

The following symbols of alleles are used in this paper: RFPL-AluI - (-) or (+) for the allele non-cut or cut by the enzyme, with $\mathrm{T}$ or $\mathrm{A}$ at pos. -1177 , respectively; RFPL-AccI - (-) or (+) for the non-cut or cut allele, with nucleotide $\mathrm{T}$ or $\mathrm{C}$ at pos. -887 ; RFPL-Fnu4HI - (-) or (+) for the non-cut or cut allele, with nucleotide $\mathrm{T}$ or $\mathrm{C}$ at pos. -1104 ; RFPL-NsiI - (-) or (+) for the noncut or cut allele, with nucleotide $A$ or $\mathrm{G}$ at pos. -154 .

The following numerical symbols were used for the GHR combined genotypes: 1 homozygote $+/+$ (cut with the respective restriction nuclease); $\mathbf{2}$ - heterozygote +/(one allele cut with the respective restriction nuclease); 3-homozygote-/-(non-cut with the respective restriction nuclease). Consecutive numbers in the combined genotype symbol indicate genotypes at GHRAluI, -AccI, -Fnu4HI, and Nsi restriction sites, respectively. For example, the combined genotype 1232 symbolises RFPL$A l u \mathrm{I}+/+$ with A at pos. -1177 ; RFPL-AccI +/- with nucleotides T/C at pos. -887; RFPL-Fnu4HI -/- with nucleotide T at pos. -1104; RFPL-NsiI +/- with nucleotides A/G at pos. -154 .

\subsection{Statistics}

The effects of single and combined genotypes on the traits studied were analysed by the least-squares method as applied in the general linear model (GLM) procedure of SAS according to the following statistical model:

$\mathrm{y}_{\mathrm{ijkl}}=\mu+\mathrm{G}_{\mathrm{i}}+\mathrm{R}_{\mathrm{j}}+\mathrm{S}_{\mathrm{k}}+\beta\left(\mathrm{x}_{\mathrm{ijkl}}-\mathrm{x}\right)+\mathrm{e}_{\mathrm{ijkl}}$ 
Table I. Means and standard deviation of analysed traits.

\begin{tabular}{lcc}
\hline Trait & $\mathrm{x}$ & $\mathrm{SD}$ \\
\hline Growth performance, feed intake and feed conversion & & \\
Live body weight at the age of 13 months $(\mathrm{kg})$ & 437.2 & 59.4 \\
Live body weight at the age of 15 months $(\mathrm{kg})$ & 513.1 & 56.99 \\
Average daily gain between 13-15 months (test period - $\mathrm{kg}$ ) & 1.43 & 0.37 \\
Dry matter (kg) & 9.42 & 1.10 \\
Dry matter (kg.kg-1 live body weight gain) & 7.1 & 2.4 \\
Carcass traits & & \\
Cold carcass weight (kg) & 292.6 & 41.7 \\
Carcass dressing percentage cold (\%) & 59.9 & 3.03 \\
Weight of valuable ${ }^{1}$ cuts in a carcass-side (kg) & 86.1 & 12.8 \\
Percentage of valuable cuts in a carcass-side (\%) & 60.8 & 1.4 \\
Percentage of lean in valuable cuts (\%) & 71.7 & 4.0 \\
Percentage of bone in valuable cuts (\%) & 16.2 & 1.6 \\
Percentage of fat in valuable cuts (\%) & 12.1 & 2.8 \\
Carcass-side dimensions (cm) & & \\
Carcass length & 162.0 & 5.7 \\
Width of the carcass over the IIIrd vertebrae & 67.8 & 3.1 \\
Round width & 42.4 & 4.0 \\
\hline
\end{tabular}

${ }^{1}$ Valuable cuts are round, shoulder, best of ribs, fore of ribs.

where:

$\mathrm{y}_{\mathrm{ijkl}}=$ studied traits;

$\mu=$ overall mean;

$\mathrm{G}_{\mathrm{i}}=$ the fixed effect of the GHR genotype

$(i=1, \ldots, 3)$, or combined genotype $(i=1$, ..., 25);

$\mathrm{R}_{\mathrm{j}}=$ the fixed effect of breed $(\mathrm{j}=1, \ldots, 5)$;

$\mathrm{S}_{\mathrm{k}}=$ the fixed effect of season at the start of fattening $(\mathrm{k}=1,2$; November-April, MayOctober);

$\beta\left(x_{i j k l}-x\right)=$ regression on the live body weight at the age of 9 months;

$\mathrm{e}_{\mathrm{ijkl}}=$ the random residual effect.

Data for all animals were analysed jointly and the effect of a breed has been included in the statistical model. The differences were tested by the Duncan test.

For the analysis of each of the four SNPs, the reference GHR genotypes were +/+, +/-, and $-1-$.
For the analysis of the combined genotypes, the expected frequencies of GHR genotypes and their combinations were calculated by simple allele counting [7]. The exact probability test was employed to evaluate possible deviations from Hardy-Weinberg equilibrium. The model includes the 25 combined genotypes that were found in the animal sample. However, in the results and tables, only the estimates of the combined genotypes found in three or more bulls are presented.

\section{RESULTS}

The means for all traits analysed and standard deviations are given in Table I.

\subsection{Single genotypes}

The effect of the single GHR genotypes on carcass traits, dry matter consumption, 
Table II. Overall least-squares means (LSM) and standard error (Se) of growth performance and carcass traits across the GHR RFLP-AluI genotypes.

\begin{tabular}{lcccccc}
\hline Trait & \multicolumn{1}{c}{$+/+(\mathrm{n}=21)$} & $+/-(\mathrm{n}=40)$ & $-/-(\mathrm{n}=10)$ \\
\cline { 2 - 7 } & LSM & Se & LSM & Se & LSM & Se \\
\hline Average daily gain between $13-15$ months (test period $-\mathrm{kg})$ & $1.26^{\mathrm{a}}$ & 0.08 & $1.47^{\mathrm{ab}}$ & 0.05 & $1.24^{\mathrm{b}}$ & 0.10 \\
Cold carcass weight $(\mathrm{kg})$ & $283.3^{\mathrm{ab}}$ & 6.4 & $297.5^{\mathrm{a}}$ & 4.6 & $300.6^{\mathrm{b}}$ & 6.5 \\
Percentage of valuable cuts & $59.8^{\mathrm{ab}}$ & 1.4 & $63.1^{\mathrm{a}}$ & 1.0 & $63.8^{\mathrm{b}}$ & 1.9 \\
\hline
\end{tabular}

a,b Within the same row values marked with the same letter are significantly different at $P \leq 0.05$.

Table III. Overall least-squares means (LSM) and standard error (Se) of growth performance and carcass traits across the GHR RFLP-AccI genotypes.

\begin{tabular}{lcccccc}
\hline \multirow{2}{*}{ Trait } & \multicolumn{2}{c}{$+/+(\mathrm{n}=18)$} & \multicolumn{2}{c}{$+/(\mathrm{n}=42)$} & \multicolumn{2}{c}{$-/(\mathrm{n}=11)$} \\
\cline { 2 - 7 } & LSM & Se & LSM & Se & LSM & Se \\
\hline Average daily gain between 13-15 months $(\mathrm{kg})$ & 1.38 & 0.8 & $1.42^{\mathrm{a}}$ & 0.06 & $1.20^{\mathrm{a}}$ & 0.1 \\
Percentage of lean in valuable cuts & $72.6^{\mathrm{ab}}$ & 0.5 & $71.5^{\mathrm{a}}$ & 0.3 & $70.9^{\mathrm{b}}$ & 0.6 \\
Width of the carcass over the IIIrd vertebrae $(\mathrm{cm})$ & $67.2^{\mathrm{a}}$ & 0.7 & $68.7^{\mathrm{a}}$ & 0.5 & 68.7 & 0.8 \\
\hline
\end{tabular}

a,b Within the same row values marked with the same letter are significantly different at $P \leq 0.05$.

Table IV. Overall least-squares means (LSM) and standard error (Se) of growth performance and carcass traits across the GHR RFLP-Fnu4HI genotypes.

\begin{tabular}{lcccccc}
\hline \multirow{2}{*}{ Trait } & \multicolumn{2}{c}{$+/+(\mathrm{n}=33)$} & \multicolumn{2}{c}{$+/-(\mathrm{n}=31)$} & \multicolumn{2}{c}{$-/-(\mathrm{n}=7)$} \\
\cline { 2 - 7 } & LSM & Se & LSM & Se & LSM & Se \\
\hline Average daily gain between 13-15 months $(\mathrm{kg})$ & $1.42^{\mathrm{a}}$ & 0.06 & 1.40 & 0.06 & $1.13^{\mathrm{a}}$ & 0.14 \\
Daily intake of dry matter $(\mathrm{kg})$ & $9.2^{\mathrm{a}}$ & 0.15 & $9.7^{\mathrm{a}}$ & 0.16 & 9.4 & 0.3 \\
Width of the carcass over the IIIrd vertebrae $(\mathrm{cm})$ & $67.6^{\mathrm{a}}$ & 0.5 & $69.2^{\mathrm{a}}$ & 0.5 & 67.8 & 1.1 \\
\hline
\end{tabular}

a,b Within the same row values marked with the same letter are significantly different at $P \leq 0.05$.

live body weight, and daily gain was stated (Tabs. II-V). The +/- heterozygous RFLPAluI GHR genotype was associated with the significantly faster growth rate between 13 and 15 months of life (during the test period), (Tab. II). During the feed intake test the $+/-$ bulls gained daily $1.47 \mathrm{~kg}$ as compared to $1.26 \mathrm{~kg}$ and $1.24 \mathrm{~kg}$ for the $+/+$ and -/- animals. As shown in Table II, the RFLP-AluI in the 5'-noncoding region of the bovine GHR gene significantly influenced some carcass traits. The weight of the cold carcass was the highest for the -/GHR genotype. The percentage of valuable cuts was the highest for the -/- genotype bulls -63.8 as compared to 59.8 for $+/+$ animals.

As shown in Table III, during the test period, the animals of the +/- RFLP-AccI genotype gained daily $1.42 \mathrm{~kg}$ as compared to $1.20 \mathrm{~kg}$ for the-/-animals. The RFLP-AccI genotype was also associated with carcass traits. The most important was the percentage of lean in valuable cuts, with the highest being in the $+/+$ genotype bulls.

In Table IV are shown associations between the GHR RFLP-Fnu4HI genotype 
Table V. Overall least-squares means (LSM) and standard error (Se) of growth performance and carcass traits across the GHR RFLP-NsiI genotypes.

\begin{tabular}{lcccccc}
\hline Trait & \multicolumn{2}{c}{$+/+(\mathrm{n}=16)$} & \multicolumn{2}{c}{$+/-(\mathrm{n}=39)$} & \multicolumn{2}{c}{$-/(\mathrm{n}=16)$} \\
\cline { 2 - 7 } & LSM & Se & LSM & Se & LSM & $S e$ \\
\hline Daily intake of dry matter $(\mathrm{kg})$ & 9.5 & 0.3 & $9.4^{\mathrm{a}}$ & 0.1 & $9.8^{\mathrm{a}}$ & 0.3 \\
Percentage of lean in valuable cuts & 71.8 & 0.6 & $71.3^{\mathrm{a}}$ & 0.3 & $72.8^{\mathrm{a}}$ & 0.6 \\
\hline
\end{tabular}

a,b Within the same row values marked with the same letter are significantly different at $P \leq 0.05$.

and traits analysed. The carcass traits significantly affected were the following: carcass width, with the highest for the $+/-$ genotype bulls. The animals with the $+/-$ genotype consumed significantly more dry matter than those of the other genotypes. The $+/+$ genotype was associated with the significantly faster growth rate between 13 and 15 months; during the feed intake test, the $+/+$ bulls gained daily $1.42 \mathrm{~kg}$ as compared to $1.13 \mathrm{~kg}$ for the $-/$ - animals.

The RFLP-NsiI genotype was associated with the daily intake of dry matter (Tab. V). The +/- genotype was associated with the least daily intake of dry matter. The percentage of lean in valuable cuts was by some 1$1.05 \%$ higher in the carcasses of $-/$ - genotype bulls than in the other genotypes.

\subsection{Combined genotypes}

Associations were studied between the combined GHR genotypes and meat production traits. Out of $81\left(3^{4}\right)$ theoretically possible combinations of 4 individual genotypes, only 25 combined genotypes were identified in the sample of animals (Tab. VI and Fig. 1). Nearly $3 / 4$ of the possible genotype combinations were missing and most of the combined genotypes found clearly escaped the Hardy-Weinberg equilibrium (Tab. VI). In most cases (except combined genotypes 1212, and 2211) the actual numbers of animals were higher than expected. The present results suggest the existence of preferable intra-genic haplotypes within the bovine GHR locus.
Table VI. Expected frequencies of combined genotypes and a comparison of observed and expected numbers of animals.

\begin{tabular}{|c|c|c|c|}
\hline \multirow{2}{*}{$\begin{array}{l}\text { Combined GHR } \\
\text { genotype }^{1}\end{array}$} & \multirow{2}{*}{$\begin{array}{l}\text { Expected } \\
\text { frequency }\end{array}$} & \multicolumn{2}{|c|}{ Number of animals } \\
\hline & & Observed & Expected \\
\hline 1133 & 0.0025 & 1 & 0.18 \\
\hline 1212 & 0.0385 & 1 & 2.74 \\
\hline 1213 & 0.0193 & 1 & 1.37 \\
\hline 1221 & 0.0179 & 1 & 1.27 \\
\hline 1223 & 0.0179 & 1 & 1.27 \\
\hline 1232 & 0.0083 & 1 & 0.59 \\
\hline 1311 & 0.0079 & 1 & 0.56 \\
\hline 1322 & 0.0147 & 1 & 1.04 \\
\hline 1323 & 0.0073 & 1 & 0.52 \\
\hline 1331 & 0.0017 & 1 & 0.12 \\
\hline 1333 & 0.0017 & 1 & 0.12 \\
\hline 2113 & 0.0172 & 1 & 1.22 \\
\hline 2211 & 0.0282 & 1 & 2.00 \\
\hline 2121 & 0.0159 & 2 & 1.13 \\
\hline 1321 & 0.0073 & 3 & 0.52 \\
\hline 1332 & 0.0034 & 3 & 0.24 \\
\hline 2223 & 0.0262 & 3 & 1.86 \\
\hline 3111 & 0.0063 & 3 & 0.45 \\
\hline 3113 & 0.0063 & 3 & 0.45 \\
\hline 1222 & 0.0357 & 4 & 2.54 \\
\hline 2111 & 0.0172 & 4 & 1.22 \\
\hline 2213 & 0.0282 & 4 & 2.00 \\
\hline 3112 & 0.0126 & 4 & 0.89 \\
\hline 2212 & 0.0564 & 8 & 4.00 \\
\hline 2222 & 0.0523 & 17 & 3.71 \\
\hline
\end{tabular}

${ }^{1}$ For combined genotype symbols, see "Materials and Methods" section. 


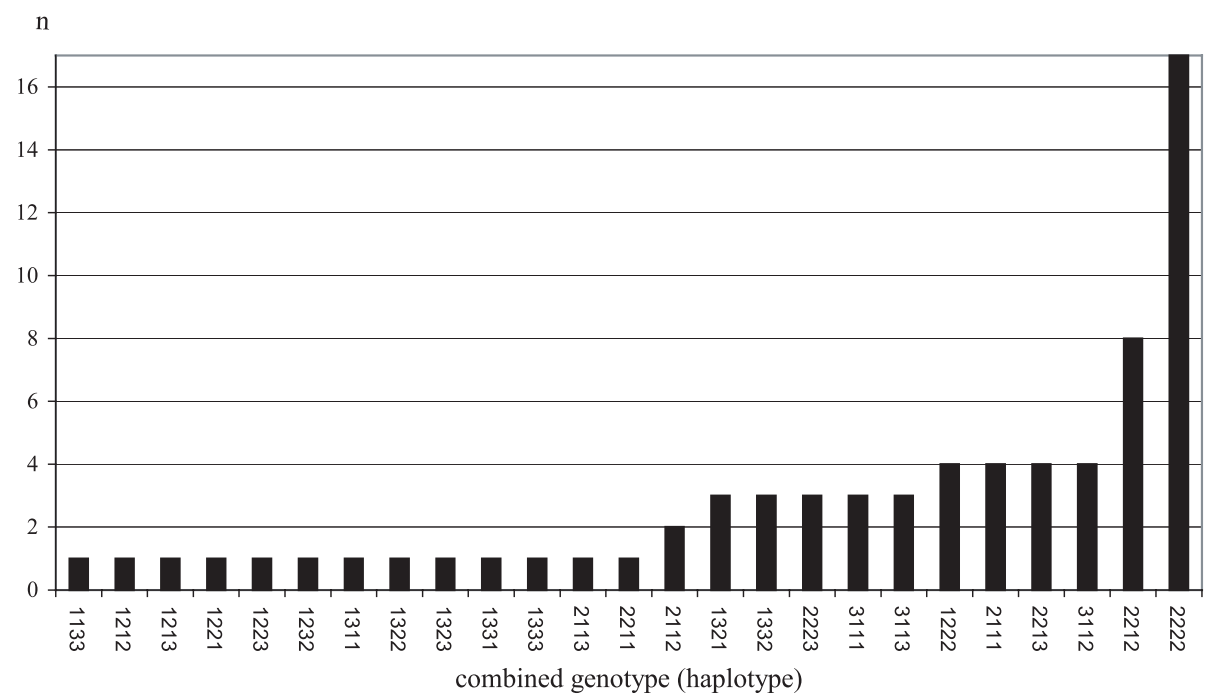

Figure 1. Frequency of combined genotypes within bovine GHR gene 5' region. Out of 81 theoretically possible combinations of four individual genotypes $\left(3^{4}\right)$, only 25 were identified in the studied group of animals (For combined genotype symbols, see "Materials and Methods" Sect.).

Some of the combined genotypes appeared to have statistically significant effects on the traits under study. Over the test period, animals carrying the 3113 or 1222 combined genotypes consumed less dry matter, as compared to those with 2222 genotype (Tab. VII). During their whole lives, the 2223 and 3112 genotype animals had shorter carcasses as compared to the others. The combined genotype 3111 was associated with a higher cold carcass weight and carcass dressing percentage. The bulls of combined genotypes 2213 and 3111 had a higher percentage of lean in valuable cuts than did those with the other genotypes (e.g. 1222, 1321).

\section{DISCUSSION}

Hormones, growth factors, and other regulatory proteins associated with so called "somatotropic axis" are candidate markers for quantitative traits in farm animals. Genes encoding for growth hormone (GH), GH receptor (GHR), transcription factor Pit-I (activating expression of $\mathrm{GH}$ and prolactin genes in the anterior pituitary), insulin-like growth factor-I (IGF-I), and perhaps genes coding for $\mathrm{GH}$ signal transduction pathways, could contribute to the progress in genetic selection of farm animals. Schlee et al. [26] showed a significant effect of the GH L/V genotype on meat breeding values of Simmental bulls. In their study, the heterozygous LV genotype was superior to LL and VV homozygotes in both carcass gain and meat value. Chrenek et al. [4] found that Simmental bulls with the VV genotype had a lower body weight in comparison to the bulls with LL or LV genotypes.

In our previous study, we found that body weight and feed intake capacity of young Friesian bulls were strongly dependent on the GH genotype; the LV heterozygotes were the heaviest and consumed the most [29]. We also showed that LL and LV genotypes were related to higher meat deposition in Friesian bulls [23], but in beef bulls the VV animals were heavier and showed higher daily gain as compared to LL 
Table VII. The effect of combined genotypes in the GHR gene 5' region on feed intake and carcass traits.

\begin{tabular}{|c|c|c|c|c|c|c|c|c|c|c|c|}
\hline \multirow[t]{2}{*}{ Trait } & \multicolumn{11}{|c|}{ Combined genotype ${ }^{1}$} \\
\hline & $\begin{array}{l}1222 \\
\mathrm{n}=4\end{array}$ & $\begin{array}{l}1321 \\
\mathrm{n}=3\end{array}$ & $\begin{array}{l}1332 \\
\mathrm{n}=3\end{array}$ & $\begin{array}{l}2111 \\
\mathrm{n}=4\end{array}$ & $\begin{array}{l}2212 \\
\mathrm{n}=8\end{array}$ & $\begin{array}{l}2213 \\
\mathrm{n}=4\end{array}$ & $\begin{array}{c}2222 \\
\mathrm{n}=17\end{array}$ & $\begin{array}{l}2223 \\
\mathrm{n}=3\end{array}$ & $\begin{array}{l}3111 \\
\mathrm{n}=3\end{array}$ & $\begin{array}{l}3112 \\
\mathrm{n}=4\end{array}$ & $\begin{array}{l}3113 \\
\mathrm{n}=3\end{array}$ \\
\hline Daily intake of dry matter $(\mathrm{kg})$ & $9.0^{\mathrm{a}}$ & 9.7 & 9.6 & 9.4 & 9.4 & 9.3 & $9.9^{\mathrm{ab}}$ & 9.2 & 9.1 & 9.4 & $8.9^{\mathrm{b}}$ \\
\hline Cold carcass weight $(\mathrm{kg})$ & $290.9^{\mathrm{a}}$ & $290.6^{\mathrm{b}}$ & $289.3^{\mathrm{c}}$ & $289.5^{\mathrm{d}}$ & 296.1 & 298.1 & $292.7^{\mathrm{e}}$ & 295.2 & $305.8^{\text {abcde }}$ & 294.7 & 293.5 \\
\hline Cold carcass dressing percentage & 59.8 & 59.9 & 59.5 & $58.4^{\mathrm{Abc}}$ & $60.4^{\mathrm{c}}$ & $61.0^{\mathrm{b}}$ & $59.6^{\mathrm{a}}$ & 59.1 & $62.0^{\mathrm{Aa}}$ & 60.1 & 60.0 \\
\hline Percentage of lean in valuable cuts & $70.0^{\mathrm{ad}}$ & $70.0^{\mathrm{bc}}$ & 70.6 & 70.9 & 70.6 & $73.2^{\mathrm{cd}}$ & 71.6 & 73.0 & $73.1^{\mathrm{ab}}$ & 72.2 & 72.8 \\
\hline Weight of bone in valuable cuts (kg) & 13.8 & 14.2 & 13.9 & $13.6^{\mathrm{b}}$ & $14.5^{\mathrm{c}}$ & 14.1 & $13.7^{\mathrm{a}}$ & 14.0 & $15.2^{\mathrm{Aab}}$ & $13.0^{\mathrm{Ac}}$ & 13.6 \\
\hline Weight of fat in valuable cuts $(\mathrm{kg})$ & $11.5^{\mathrm{ae}}$ & 10.8 & $11.2^{\mathrm{b}}$ & 11.1 & $11.2^{\mathrm{c}}$ & 9.4 & 10.4 & $8.8^{\mathrm{abcd}}$ & 9.3 & $11.0^{\mathrm{d}}$ & $9.1^{\mathrm{e}}$ \\
\hline Carcass length & 160.9 & $166.0^{\mathrm{ad}}$ & $164.9^{\mathrm{be}}$ & 161.7 & 161.4 & $163.1^{\mathrm{cf}}$ & 163.4 & $157.6^{\mathrm{abc}}$ & 161.9 & $158.6^{\mathrm{def}}$ & 163.0 \\
\hline $\begin{array}{l}\text { Width of the carcass over the IIIrd } \\
\text { vertebrae }\end{array}$ & 68.9 & $69.8^{\mathrm{a}}$ & 68.9 & 66.5 & 67.7 & 67.6 & 69.7 & $69.8^{\mathrm{b}}$ & 67.7 & 68.3 & $65.9^{\mathrm{ab}}$ \\
\hline
\end{tabular}

Within the same row values marked with the same letter are significantly different:

a,b,... - at $P \leq 0.05$; and ${ }^{\mathrm{A}}$ - at $P \leq 0.01$.

${ }^{1}$ For combined genotype symbols, see "Materials and Methods" section. 
and LV genotypes [30]. In the study of Parmentier et al. [25] the superior effect of allele A of the Pit-I transcription factor was shown for conformation traits in HolsteinFriesian cattle - body depth, angularity, and rear leg set.

Only a few authors reported on the effects of GHR gene polymorphism on the production traits in cattle. Hale et al. [12] have shown a correlation between variable GTrepeat in the $\mathrm{P} 1$ promoter of the bovine $\mathrm{GH}$ receptor gene, and growth rates in young Angus cattle; the $\mathrm{TG}_{11} \mathrm{GH}$ receptor allele is associated with lower growth rates in Angus steers. Falaki et al. [6] reported on the effect of RFLP-TaqI in the GHR gene 3 ' end on breeding value for milk protein in Italian Holstein-Friesian cattle. Aggrey et al. [1] have shown associations between the polymorphism at the AluI site in the 5'-noncoding region of the GHR gene and milk production traits. Holstein bulls with the AluI (+/+) genotype of the GHR gene had a higher breeding value for milk fat than bulls with the (-/-) genotype. Recently, Blott et al. [2], using the QTL approach, have shown an association of the Phe/Tyr polymorphism in the transmembrane domain of the bovine $\mathrm{GH}$ receptor with a major effect on milk yield and composition.

In this study, the associations were shown of polymorphism at four sites within the 5'-noncoding region of the bovine GHR gene with traits related to beef production. All polymorphisms studied were single nucleotide polymorphisms (SNPs). Three of them (RFLP-AluI, -AccI, and -Fnu4HI) were located within the 1.2-Kb LINE-1 element, a retrotransposon of viral origin, inserted in the bovine GHR gene 5'-region. The fourth polymorphic site - RFLP-NsiI - was located within the $\mathrm{P} 1$ promoter for exon $1 \mathrm{~A}$.

The SNPs in the protein-coding genes have gained high popularity in genetic studies because their estimation is highly accurate and reproducible. Moreover, they are indispensable in searching for candidate genes [27]. These markers are less polymorphic than non-coding repetitive sequences, but the advantage of analysing polymorphism of protein coding genes is that they may be directly involved in determining important traits in farm animals.

Summarising the effects of the GHR gene polymorphism on the traits studied the following preliminary conclusion could be drawn: (1) The (-) allele at the polymorphic AluI site appeared favourable for several meat production-related traits. The $-/-$ or $+/-$ genotype animals were superior for such traits as average live daily gain to slaughter, weight of carcass and weight of lean in carcass. For none of the traits considered, the animals of the $+/+$ genotype appeared better than heterozygotes or -/- homozygotes. These results might indicate either a favourable influence of the allele (-) or of a disadvantageous effect of the allele (+) to the traits tested. (2) It is difficult to conclude on the associations between the RFLP-AccI and the meat production traits. Nevertheless, animals with the +/+ genotype seemed better for percent of lean in valuable cuts. (3) The animals with $+/+$ genotype and allele (+) at the polymorphic Fnu4HI site appeared superior for most traits studied. They grew faster and consumed less feed. Thus, our results might suggest the superiority of the $+/+$ genotype, and possibly allele (+), for the meat production traits in the beef cattle under study. (4) Feed intake and most carcass traits, were better for the young bulls of $-/-$ or $+/-$ genotypes at the GHR Nsi site. These results might suggest a favourable influence of the allele (-) or on a disadvantageous effect of the allele ( + ) to the traits tested.

Moreover, this study showed associations between combined genotypes and the meat performance traits. For example, bulls with 2222 genotype (heterozygous +/- at AluI, AccI, Fnu4HI, and NsiI sites) consumed statistically more feed (expressed as dry matter), while the lowest cold carcass weight was recorded for animals with combined genotypes 2111 and 1332 .

In this study, the outbred populations were used without family structure. Thus, there 
was no possibility of studying the segregation of alleles and their effects on traits within a family. For the same reason, the identification of genuine haplotypes was not possible, and instead the combined genotypes were used to estimate associations with meat production traits. The separate analysis of each SNP might not provide independent results if SNPs are in linkage disequilibrium. Indeed, the comparison of the actual and expected frequencies of the combined GHR genotypes showed that they might have escaped the Hardy-Weinberg equilibrium and that preferable intra-genic haplotypes exist within the bovine GHR locus.

In summary, our present results showed associations between genetic variants at the 5 '-noncoding region of the bovine GHR gene and beef production traits and other traits related to meat production, including growth performance, feed intake, and carcass traits. However, to draw final conclusions, these studies should be extended to a larger and more homogenous population of cattle, preferably with the use of a reference family.

\section{ACKNOWLEDGEMENTS}

The authors thank Ms Barbara Rowińska for the genotype analyses. This study was funded by the State Committee for Scientific Research (KBN) grant PBZ-KBN-036/P06/12 and by IGAB PAS project S.I.-2.2.

\section{REFERENCES}

[1] Aggrey S.E., Yao J., Sabour M.P., Lin C.Y., Zadworny D., Hayes J.F., Kunlein U., Markers within the regulatory region of the growth hormone receptor gene and their association with milk-related traits in Holsteins, J. Hered. 90 (1999) 148-151.

[2] Blott S., Kim J.J., Moisio S., Schmidt-Kuntzel A., Cornet A., Berzi P., Cambisano N., Ford C., Grisart B., Johnson D., Karim L., Simon P., Snell R., Spelman R., Wong J., Vilkki J., Georges M., Farnir F., Coppieters W., Molecular Dissection of a Quantitative Trait Locus.
A phenylalanine-to-tyrosine substitution in the transmembrane domain of the bovine growth hormone receptor is associated with a major effect on milk yield and composition, Genetics 163 (2003) 253-266.

[3] Burton J.L., McBride B.W., Block E., Glimm D.R., Kenelly J.J., A review of bovine growth hormone, Can. J. Anim. Sci. 74 (1994) $167-$ 201

[4] Chrenek P., Kmet J., Sakowski T., Vasicek T. Huba J., Chrenek J., Relationships of growth hormone genotypes with meat production traits of Slovak Pied bulls, Czech J. Anim. Sci 43 (1998) 541-544.

[5] Etherton T.D., Bauman D.E., Biology of somatotropin in growth and lactation of domestic animals, Physiol. Rev. 78 (1998) 745-761.

[6] Falaki M., Gengler N., Sneyers M., Prandi A., Massart S., Formigoni A., Burny A., Portetelle D., Renaville R., Relationships of polymorphisms for growth hormone and growth hormone receptor genes with milk production traits for Italian Holstein-Friesian bulls, J. Dairy Sci. 79 (1996) 1446-1453.

[7] Falconer D.S., Mackey T.T.C., Introduction to quantitative genetics, fourth edition, Longman Group Ltd, Essex, England, 1996.

[8] Ge W., Davis M.E., Hines H.C., Irvin K.M., Two-allelic DGGE polymorphism detected in the promoter region of the bovine GHR gene, Anim. Genet. 30 (1999) 71.

[9] Ge W., Davis M.E., Hines H.C., Irvin K.M., Simmen R.C.M., Association of single nucleotide polymorphisms in the growth hormone and growth hormone receptor genes with blood serum insulin-like growth factor I concentration and growth traits in Angus cattle, J. Anim. Sci. 81 (2003) 641-648.

[10] Goodyer C.G., Zogopoulos G., Schwartzbauer G., Zheng H., Hendy G.N., Menon R.K., Organization and evolution of the human growth hormone receptor gene 5'-flanking region, Endocrinology 15 (2001) 1923-1934.

[11] Grochowska R., Gajewska A., Snochowski M., Zwierzchowski L., Ligand-binding activity of growth hormone receptor (GHR) in bulls of different breeds with identified GHR genotypes, J. Anim. Feed Sci. 11 (2002) 223236.

[12] Hale C.S., Herring W.O., Shibuya H., Lucy M.C., Lubahn D.B., Keisler D.H., Johnsson G.S., Decreased growth in Angus steers with a short TG-microsatellite allele in the $\mathrm{P} 1$ promoter of the growth hormone receptor gene, J. Anim. Sci. 78 (2000) 2099-2104. 
[13] Jarrige R., Ruminant nutrition, recommended allowances \& feed tables, INRA, John Libbey Eurotext, London-Paris, 1989, 214 p.

[14] Jiang H.L., Lucy M.C., Involvement of hepatocyte nuclear factor- 4 in the expression of the growth hormone receptor $1 \mathrm{~A}$ messenger ribonucleic acid in bovine liver, Mol. Cell. Endocrinol. 15 (2001) 1023-1034.

[15] Jiang H.L., Lucy M.C., Variants of the 5'untranslated region of the bovine growth hormone receptor mRNA: isolation, expression and effects on translational efficiency, Gene 265 (2001) 45-53.

[16] Kanai N., Fujii T., Saito K., Yokoyama T., Rapid and simple method for preparation of genomic DNA from easily obtained clotted blood, J. Clin. Pathol. 47 (1994) 1043-1044.

[17] Kopchick J.J., Andry J.M., Growth hormone $(\mathrm{GH})$. GH receptor and signal transduction, Mol. Genet. Metab. 71 (2000) 293-314.

[18] Lucy M.C., Johnsson G.S., Shibuya H., Boyd C.K., Herring W.O., Werin M., Rapid communication: Polymorphic $(\mathrm{GT})_{\mathrm{n}}$ microsatellite in the bovine somatotropin receptor gene promoter, J. Anim. Sci. 76 (1998) 2209-2210.

[19] Maj A., Zwierzchowski L., New RFLPFnu4HI polymorphism within the 5'-flanking region of the bovine growth hormone receptor gene, VIII Polish Conference on Cell Biology, Wrocaw, 23-25 September 2002, Cell. Mol. Biol. Lett. 7 (Suppl.) (2002) 305.

[20] Menon R.K., Shaufl A., Yu J.H., Stephan D.A., Friday R.P., Identification and characterization of a novel transcript of the murine growth hormone receptor gene exhibiting development and tissue-specific expression, Mol. Cell. Endocrinol. 172 (2001) 135-146.

[21] Moisio S., Elo K., Kantanen J., Vilkki J., Polymorphism within the 3'-flanking region of the bovine growth hormone receptor gene, Anim. Genet. 29 (1998) 55-57.

[22] Moody D.E., Pomp D., Barendse W., Womack J.E., Assignment of the growth hormone receptor gene to bovine chromosome 20 using linkage analysis and somatic cell mapping, Anim. Genet. 26 (1995) 341-343.

[23] Oprzạdek J., Dymnicki E., Oprzạdek A., Słoniewski K., Sakowski T., Reklewski Z., A note on the effect of breed on beef cattle the carcass traits, Anim. Sci. Papers Reports 19 (2001) 79-89.

[24] Oprzạdek J., Dymnicki E., Zwierzchowski L., Łukaszewicz M., The effect of growth hormone $(\mathrm{GH})$, $\kappa$-casein (CASK), and $\beta$-lactoglobulin (BLG) genotypes on carcass traits in Friesian bulls, Anim. Sci. Papers Reports 17 (1999) 85-92.

[25] Parmentier I., Portetelle D., Gengler N., Prandi A., Bertozzi C., Vleurick L., Gilson R., Renaville R., Candidate gene markers associated with somatotropic axis and milk selection, Domest. Anim. Endocrin. 17 (1999) 139-148.

[26] Schlee P., Graml R., Rottman O., Pirchner F., Influence of growth-hormone genotypes on breeding values of Simmental bulls, J. Anim. Breed. Genet. 111 (1994) 253-256.

[27] Vignal A., Milan D., SanCristobal M., Eggen A., A review on SNP and other types of molecular markers and their use in animal genetics, Genet. Sel. Evol. 34 (2002) 275-305.

[28] Zhu T., Goh E.L.K., Graichen R., Ling L., Lobie P.E., Signal transduction via the growth hormone receptor, Cell. Signal. 13 (2001) 599-616.

[29] Zwierzchowski L., Lukaszewicz M., Dymnicki E., Oprządek J., Polymorphism of growth hormone, $\kappa$-casein (CASK), and $\beta$-lactoglobulin (BLG) genes in growing Friesian cattle, Anim. Sci. Papers Reports 16 (1998) 61-68.

[30] Zwierzchowski L., Oprzadek J., Dymnicki E., Dzierzbicki P., An association of growth hormone, $\kappa$-casein, $\beta$-lactoglobulin, leptin, and Pit-1 loci polymorphism with growth rate and carcass traits in beef cattle, Anim. Sci. Papers Reports 19 (2001) 65-77. 